\title{
Causal Relationship of Stock Performance and Macroeconomic Variables: Empirical Evidences from Brazil, Russia, India and China (BRIC)
}

\author{
Wang Bin \\ Centre for Postgraduate Studies \\ Nilai University, Malaysia \\ Dr. Evelita E. Celis \\ Henley Business School Malaysia \\ University of Reading Malaysia
}

\begin{abstract}
The rise of BRIC (Brazil, Russia, India and China) in the global investment market is still too mysterious to investors. This paper attempts to investigate the causal relationship among quarterly returns of BRIC's stock market indices using a set of pre-examined macroeconomic variables such as, economic growth (GDP), risk free rates (the U.S. t-bill rates), exchange rates against USD, international oil prices and inflation in order to understand the leading factor of BRIC's stock market returns. This paper covers the sample period from 1996:Q4 to 2013:Q1. The error correction model and Granger causality approach were applied to investigate the relationship among the variables. The results indicate that none of the explanatory variables Granger cause stock market performance in China and India. In homogenous, there is Granger causality from BRIC's stock market performance to the risk free rates and international oil prices. This finding implies that BRIC has strong market impact or purchasing power to influence the key raw input of an economy, as well as the largest risk free investment instrument in the world. Generally, the Fed model, international trading effect and portfolio balance model are inapplicable to BRIC. The safest investment guidance for investors is to follow the changes in oil prices to forecast the movement in stock performance in Brazil. This is because there is an actual sign (from the error correction model) and significant pairwise Granger causality between stock market returns and oil prices in Brazil.
\end{abstract}

Keywords: stock market performance, macroeconomic variables, granger causality, risk free rates; unit root tests, cointegration tests

\section{INTRODUCTION}

Under the conceptual framework of the Keynesians, stock performance is not a reflection of the market value of stocks, but instead a discipline, which acts as an effective mechanism supplying the equity landscape with essential stability and liquidity for investments (Keynes, 1936). In brief, so long as the discipline remains, the capital market will grant investors safety in short-term investments, while the stability circulates the flows of liquidity accordingly. However, as time goes on, the Keynesian elucidation in depicting the vividness and vibrancy of investment has become ever inapplicable in the reality. This is because the revolution in technological support and speculation strategies has been gradually melting the balance of investment discipline. Frequent occurrences of financial crises also make the movement of instrument prices a financial puzzle to both investors and econometricians. Thus, the necessity of forming new tentative hypotheses is pressing for academicians to stabilize and recover the functions of equity market, again. 
The random walk hypothesis postulates that stock market prices move in the light of a random walk, and could not be predicted under a predefined specification (Cootner, 1962; Samuelson, 1965). In this conceptual foundation, Fama $(1965 ; 1970)$ formed the efficient market hypothesis asserting that informational efficiency is the core mechanism of financial markets. Investors are unable to constantly attain excessive returns over the average market returns on a risk-adjusted basis, based on the contemporarily available information at the time the decision is realized. If either hypothesis holds, stock price movements will become unpredictable or less predictable unless one has superior information over the majority of investors involved. However, history has showed that many renowned investors have consistently beaten the market, while numerous empirical evidences have proven that stock market performance is linked to a set of economic forces. Hence, the effort to sort the set of economic fundamentals to explain the stock price movement is not vain, unlike what the random walk hypothesis asserts.

In 1976, Ross held that macroeconomic factors can be significant to forecast the expected return under a linear function, where elasticity to varies in each factor is represented by a factor-specific beta coefficient. According to the arbitrage pricing theory, if the future price diverges from the model-derived output, arbitrage opportunities will be presented and realized to direct the stock price back to correct level. Chen et al. (1986) suggested that inflation, gross national products, investor confidence and yield curve are significant in explaining stock market performance. However, low frequency of national statistics is likely to impair the estimation accuracy. Thus, several additional indicators are provided by following researchers, such as influential stock market performance, commodity prices, U.S. 3-month Treasury bill rates and currency exchange rates (Dornbusch and Fisher, 1980; Sadorsky, 1999; Soydemir, 2000; Bilson et al., 2001; Kim, 2003; Quayes and Jamal, 2008).

Generally, the reported results are inconsistent across the different research backgrounds. The same set of variables can be significant to explain the stock price movement in one country, but could be totally irrelevant for another economy. This paper aims at formulating a set of explanatory variables to significantly predict the prospective directions of stock price tendency. Brazil, Russia, India and China (BRIC) are the key research context of this paper. Since these economies are experiencing dynamic growth, an investigation on this background can provide investors some insights regarding the influences of macroeconomic variables to the emerging economies. The most adopted variables, such as gross domestic products, U.S. 3-month Treasury bill rates, currency exchange rates and commodity prices, are inclusive in the model specification. This paper applied a combination of error correction model and granger causality approach to sophisticatedly examine the causality between the variables, and investigate the sensitivity of each variable in explaining the stock price evolution.

\section{Research background}

The core research background of this paper is the rapidly growing economic region, which contains Brazil, Russia, India and China, or the abbreviation of BRIC. BRIC was coined by Jim O' Neill (2001) to describe the phenomenon of fast developing countries: Brazil, Russia, India and China. Over the past two decades. BRIC has experienced enormous economic growth owing to the abundance of its natural resources, comparative advantage in labour cost and extensive manpower. This economic condition is similar to the pre-developed economic status of current developed countries, which means from the development of BRIC, we may observe the transversion from a developing economy to a developed economy. Thus, BRIC is considered as a bridge which connects the gap between first world countries 
and third world countries. This paper may provide readers a pre-emptive view regarding the future macroeconomic determinants of stock performance for the normal developing countries, such as Vietnam and Philippines. An understanding related to the lead factors of stock performance is pivotal to both investors and country governors since an accurate prediction is able to minimize potential losses associated with the market turbulence.

\section{Problem statement}

Due to economic saturation and the prevalence of humanitarian, developed countries are facing the issues of uncompetitive wages and rentals, severe market competition, stringent environmental protection costs, etc. To deal with these problems, numerous sizeable corporations from developed countries have expanded their offshore operations in developing countries. The tide of offshoring actions greatly stimulates economic growth of several countries, for example, BRIC. These countries rapidly absorb the technological transfers and capital flows from developed countries and progressively approach the territory of sound economic development.

Global investors are attracted by the booming condition of BRIC and trying to speculate BRIC's stock market performance. Stock market volatility of BRIC has been elevated to a more fluctuated level while this zero sum game greatly widen the chasm between the wealthy and poor. Besides, insider information is obviously observable in these markets since BRIC's members usually do not have strict regulation prohibiting insider trading. Comparing with huge-size investors, scattered investors are more likely to suffer from the exposure of ignorance. Thus, these issues raise the needs of formulating a set of predefined leading indicators to reduce the imbalanced investment positioning between institute and individual investors.

This paper intends to provide academicians and practitioners two sensible insights regarding the causality and association between macroeconomic variables and stock performance in BRIC. First, although there were many researchers analysing the global phenomenon or regional trend, the regional concordant research pertinent to BRIC was not carried out by any previous researcher. The similarity or homogeneity of variables in explaining the stock price movement has yet to be identified. Second, theoretically, a lack of significant variables might deteriorate the explanatory power or result consistency of a model, while redundancy of exceeding variables could incur the problem of multicollinearity and serial dependence. Aforementioned, the same set of variables can be significant for a country, while it could be totally irrelevant to another economy. The poor generalisation of variables requires a customization process to match the variables with the associated economic characteristics.

Although many empirical researches have proven the long-term leading status of macroeconomic variables to explain stock market performance, this idea is not consistent with the Efficient Market Hypothesis (EMH). According to EMH, an efficient market will rapidly incorporate the value of information associated with the market efficiency level, although the speed to absorb information might vary from one country to another country (Cooray, 2003; Malkiel 2003; Celis 2015). Usually, the velocity of reflecting new information will range from few seconds to few days. The leading status of macroeconomic variables might oppugn the speed of information incorporation for the stock market. The definition of "rapid" in the Efficient Market Hypothesis is questioned by the real world incidences. Thus, the Granger causality test(Granger, 1969), which is a statistical hypothesis test used to make sure whether one time series can forecast another time series under the specification of error correction model is employed to observe the direction and significance of each variable to another variable. 


\section{Research objectives}

The purpose of generalizing preceding researches and revisiting the existing findings pertinent to BRIC is the core objective of this paper. Since previous researchers have identified the significant variables to explain the variation in stock performance, this paper intends to sort out the causality of the nexus of stock performance, economic growth, risk free rates, real interest rates and exchange rates.

Several secondary objectives of this paper are listed below:

1. To examine the causal relationship between stock performance and economic fundamentals.

2. To explore the homogeneity of explanatory variables in explain the variation in stock performance.

\section{Significance of this research}

The formation of BRIC provides this paper an opportunity to analyses the causal impact and economic momentum of macroeconomic fundamentals to stock performance under the research content of a rapidly developing region. The core significance of this study is to identify the relationship among stock market performance and macroeconomic variables in BRIC. Although the BRIC members do share a similar economic condition, different economies might have dissimilar kinds of causality among the variables.

This paper employs the background of BRIC to examine the causality and model specification of the relationship among stock performance, currency exchange rates (Pebbles and Wilson, 1996), economic growth (Ferson and Harvey, 1998), risk free rates (Bilson et al., 2001) and commodity prices (Apergis and Miller, 2009). Since the explanatory power of each variable is subject to the issue of endemicity, the findings from this paper might provide readers a guidance to the factor selection in consistent with the characteristics of the rapidly emerging economies. These variables are not only empirically significant in explaining the variation in stock performance, but also fitted in the theoretical framework. Both the theoretical and empirical relationship of these macroeconomic variables with stock performance will be discussed in the section of literature review. After going through this study, readers could get some insights regarding the impacts of each macroeconomic variable on stock market returns and obtain a set of significant leading indicators on forecasting the future direction of stock market tendency.

This paper applies a comprehensive approach, which combines both the Johansen cointegration test and a Granger causality approach, to examine the nexus as well as the dynamics of each explanatory variable to the variation in stock market performance. Johansen cointegration test (1991) was used to examing cointegration of several time series at 1st difference, and also allows many cointegrating relationships. Throughout this study, readers may understand both the long run and short run impacts of the explanatory variables to the variation in stock performance.

\section{Efficient market hypothesis}

\section{LITERATURE REVIEW}

According to Fama $(1965 ; 1970 ; 1995 ; 1998)$, stock price movements are independent from their previous positioning, or random walking regardless of human psychological reactions, more precisely. This kind of random behavior in stock price movements could be mainly explained by the unexpectedness of the presence of new information arriving in the market 
(Dimson and Mussavienm, 2000; Malkiel, 2005). When the new information has been rapidly reflected in the stock price, this rapidness prohibits late comers to gain any leftover and also disallows early birds to sustain their profits in a long run (Timmermann and Granger, 2004). In other words, using historical data or technical analysis provides no leading symptom on the stock price prediction (Fama, 1991). Therefore, an efficient market follows the risk and return tradeoff on the matter of adjusting investors' profits within the probability mechanism.

Based on the random walk hypothesis, Fama (1965) coined the conceptual framework of the efficient market hypothesis, which suggests that the only adjusting stimuli of stock price movements are the value of new information. Since the value of new information is homogenous to all investors, investors should reasonably react to the new information and reflects their rational judgments in their holding lots. In simple, following the efficiency of the market and the rationality of investors, stock price movements should be only correlated with the magnitude of new information in a blink period. However, the rapidness of incorporating new information in the stock price does not imply an instant response from investors (Fama and French, 1988). Thus, temporary memory or past innovation is transitorily involved in the adjustments of stock prices.

The efficient market hypothesis receives international evidences on the task of explaining the stock market sentiment, for example, the U.S. (Uri and Jones, 1990), Asia-Pacific countries (Groenewold and Ariff, 1998), African countries (Smith et al., 2002), developed European countries (Borges, 2008) and etc. Previous research commonly adopted the multiple variance ratio test and the run tests to observe the randomness of stock price movements in the account of previous lagged terms. In general, developed stock markets have greater market efficiency than developing stock markets because of better investors' rationality, trade openness, liquidity and soundness of the transaction platform.

Nevertheless, the generalization of the efficient market hypothesis has been oppugned by a number of academicians and practitioners over the past few decades (Jensen, 1978; La Porta et. al., 1997; Malkier, 2005). The over-simplistic assumptions of the efficient market hypothesis cause the hypothesis inapplicable to the real world. The lacks of rational investors (Jacobsen, 1999), homogenous expectations (Hunter and Coggin, 1988) and accessibility to information (Green, 2004) in the stock market impairs the practical soundness of the efficient market hypothesis. According to Evans (1968), the active stylish investment strategy is more superior to the passive holding strategy because the market rewards investors with skillful investment techniques. The inherent differences among the investors diverge the action of one investor from the other investors towards the same information, ceteris paribus.

In comparison to the supports of the efficient market hypothesis, a greater number of researchers contradicted the actual practicability of the hypothesis in the market (Umstead, 1976; Keim and Stambaugh, 1986; Hawavini and Keim, 1994; Collin and Hribar, 1999; Malkier, 2003; Miambo and Biekpe, 2007; Daniel and Titman, 2012). The most renowned example of the fundamental analyst is Warren Buffet, who has consistently beaten the market via his subtle insight, with or without his market impact. Although some might argue that the presence of outstanding investors is of a pure outlier, this fact is undeniable in the reality.

\section{Stock performance and economic output}

Empirical studies suggest that there is a plausible relationship between macroeconomic variables and stock performance, given that the movements of stock price are the present 
value discounted from the aggregate sum of future economic benefits. If the inflows of future economic benefits are a function of real economic activity, a causal relationship between economy and stock price should exist (Duca, 2007). If investors hold homogenous expectations towards corporate future economic benefits are accurate, the standard discounted-cash-flow model should be reasonable enough to bridge the linkage between stock performance and economic activities. Currently, there are three theoretical propositions explaining the direct impact of stock performance to economic output.

The first proposition was raised by Tobin (1969). He suggested that high share prices might lead to a correspondingly high replacement cost of the stock of corporate capital. This situation elevates investment expenditures and aggregate economic outputs as firms find it easier to finance their investment expenditures. These lead and lag linkages can be embodied from a coefficient known as Tobin's Q, which is a ratio of the market value of current capital to the cost of replacement capital. This occurs because investment would be easier as it would require a lower share offering in a situation of a high share price.

The second proposition which variation in stock market performance may correlate with GDP was initiated by Modigliani (1971). His proposition holds that wealth is a function of consumption, as an increase in stock prices could elevate the investors' wealth reserves, resulting in higher income in an economy. In Modigliani's (1971) permanent income hypothesis, consumers optimize consumption for the sake of maximizing their utility function. Thus, the positive impacts of permanent income will always adjust the consumption level periodically, in accordance to the changes in permanent income levels/

The last proposition which links stock prices to macroeconomic outputs is lying within the mechanism of financial accelerator (Bernanke and Gertler, 1989; Kiyotaki and Moore, 1997). This empirical view suggests that stock prices are a preliminary view of a firm's financial position and physical fundamental. As the issue of asymmetric information presents in credit markets, lenders usually evaluate a firm's credibility and solvency from the amount of collateral that could be pledged by the firm. Since the value of collateral is always relating to a firm's stock prices, movements in stock prices could adjust the firm's abilities to borrow, which subsequently decide the number of investment opportunities can be executed, and thereby the development degree of an economy can vary.

To substantiate the impact of stock performance to growth, Levine and Zervos (1998) investigated the correlation between stock market development and economic growth in 47 OECD countries, and documented that there is a positive correlation between stock market and economic outputs. However, their approach is subject to the limitation of cross-sectional methods and does not significantly generalize the causal relationship between stock market and economic growth worldwide. According to Salahuddin (2010), the conventional literature was exposing to the problem of over-focus on the stagnant level of manpower or productivity, but not on the improvement in growth, in explaining the growth progress in an economy. Thus, the conventional literature can only act as a reference, but not a conceptual framework, in formulating the relationship between stock markets and economic growth. Thus, a shift in the concerns on the growth function provides some valuable insights regarding the relationship between stock market and economic growth, specifically, the endogenous growth theory postulates that growth is endogenously sustaining and influenced by local conditions. In the context of the endogenous growth theory, the stock market is not an ignorable scheme under the term "ceteris paribus", but a vibrant function indirectly reflect the growth in an economy. 
However, this framework is not a perfect solution explaining the function of growth. The controversy mainly derived from the view that stock market development improves growth in the long run. Greenwood and Smith (1996) indicated that stock markets promote the mobilization of saving circulating among the companies, which provides funds to the most productive companies and diversify investors' risks. Obstfeld (1994) claimed that international stock market integration facilitates the allocation of scarce resources to the most vibrant countries without compromising the optimal efficiency of international capitals. Bencivenga et al. (1996) and Levine and Renelt (1992) suggested that stock market liquidity plays a critical roles in improving economic growth. On one hand, adequate liquidity minimizes transaction costs and spreads for trading stock. These benefits can result in reducing the holding and transactions expenses (and exposures) of investors since their portfolios can be adjusted at a low costs and are subject to lower barrier to exit. One the other hand, investments in productive companies would make investors resisted to realize their profits, and thereby consistent commitments of investors promote the stability of economic outputs (Holmstrom and Tirole, 1993).

Moreover, Atje and Jovanovich (1993) documented that there is strong positive correlation between the degree of financial market development and economic growth in 40 countries over the period from 1970 to 1988. Levine and Zervos (1998) highlighted that economic growth is positively influenced by stock market liquidity and the size of the economy. This causal relationship is also generalized in Asian countries (Fase and Abma, 2003), Belgium (Nieuwerburgh et al., 2005) and the European Union (Wu et al., 2009). Empirical evidences suggested that banking development can be a substitute of stock market development in explaining economic growth since banks have a similar function as a stock market in circulating the saving surplus units (e.g. individuals) to the fund deficit units (e.g. corporate). This implies that economic growth can be facilitated by a sophisticated banking mechanism. Cole et al. (2008) found that bank stock returns are positively linking to the degree of economic growth.

Several conceptual ideas about the expansion of stock markets can be abstracted from the literature. Demirguc-Kunt and Maksimovic (1996) stressed that stock markets do not expand in an isolated way, neither, does the development of stock markets directly squeeze out the position of banking and financial intermediaries in the aggregate mechanism of corporate funding. Instead, economic development drives the expansion of stock markets, clearly because of capital accumulation leads to an elevation of liabilities financing to corporate. If economic growth is a function of stock market development, the liabilities financing in an economy will be increasing at low degrees of inboard capital accumulation, and eventually decreasing once the stock market has an adequate capacity to absorb corporate demands in external funds (Atje and Jovanovich, 1993; Beck and Levine, 2001). Therefore, an improvement in economic development will simultaneously facilitate the expansion of stock markets, as well as an increase in the usage of equity financing in the country.

Schwert (1989) investigated the causal relationship between stock market development and economic growth by documenting the correlation stock performance and economic outputs. He suggested that stock performance seriously depends on the stability of an economy and fluctuation in economic conditions could significantly impair overall stock returns. Humpe and Macmillan (2005) lend supports to the impacts of macroeconomic variables on stock market performance in developed economies. They documented that an increase in industrial outputs will result in a positive maneuver in stock prices. In Campbell's (1998) work, he found stock performance has relatively weaker predictive power to economic 
growth, while economic outputs are significant to explain the variation in stock movements in 5 developed countries. However, Campbell's results were not agreed by Binswanger (2004) and Stock and Watson (2001) as the relationship could vary as time goes on. Contemporary, stock market performance is a predictive determinant to economic growth to developed economies.

A number of literature hold that there is positive relationship between stock market development and economic growth. The empirical conclusion consistently substantiate the view that economic growth could be a function of stock market performance, as the healthiness of economy could stably improve the economic performance, or broadly, the aggregate form of all corporate within the economy (Korajczyk, 1996; Levine and Zervos, 1998; Blackburn et al., 2005; Rahman et al., 2009). Nevertheless, previous empirical studies have not concluded a monotonic development of stock markets in the financial mechanism. Salahuddin (2010) claimed that the expansion in stock markets is a precedent to the development of the financial system, as well as market efficiency. The evaluation of the determinant of stock market is rooted in a complex and multifaceted macroeconomic puzzle. Therefore, instead of solely investigating the pairwise-relationship between stock market performance and economic growth, more macroeconomic variables should be added to crowd out the gross effect of economic growth on stock market performance, and further sort out the individual impact of each macroeconomic variable on stock markets.

\section{Macroeconomic variables and stock market performance}

Apart from the economic output, empirical studies suggest that there are five main significant determinants that affect stock price and its volatility: energy prices, exchange rates, inflation and interest rate. The concept of opportunity cost and allocation of scarce resource explains the reason why these macroeconomic variables affect the stock market in an alternative form (Farnham, 2009; Samuelson, 2010). Since investors do not possess infinite resources for investments, they could only participate in the investment that forgoes the lowest opportunity costs. Namely, an increase in cash flows in the stock market will definitely shrink the capital available for other investment markets. An invisible hand of the markets will adjust the prices of associated investment instruments in accordance to the change in demand and supply in those related instruments. For instance, empirical evidences report a negative relationship between stock prices and gold prices during the recession (Tully and Lucey, 2005), or inverse correlation between stock prices and interest rates during the booming period (Uddin, 2009).

The international integration of economies has also assisted in shifting the local investment behavior to the international ballgame (Garefalakis et al., 2011). The globalization in crossnational financial markets has harmonized the interrelationship among different investment instruments and elevated the accessibility of financial markets to a reasonable approach of global investors regardless their local economic conditions. Besides, a loose in financial regulations liberalizes financial markets from the constraint of governments. As a consequence of these reasons, financial investors have embarked on international trading to reduce their personal exposure via the mean of incorporating alternative investment instruments in their portfolios. The beneficial effect of alternative investments on minimizing the portfolio risk was documented in the studies conduct by Holmes (2006), Gilbert (2008) and Sariannidis (2010). 


\section{Oil prices}

Recently, the effect of oil prices on stock returns has received considerable attention. This follows largely from the fact that if oil prices affect economic activities, then it follows that oil prices will affect the stock market. If high oil prices lead to a slower pace of economic activities and higher inflation, this affects consumers and producers alike by dampening consumption and investment, and these adversely affects the stock markets (Chen, 2010). Theoretically, oil price shocks affect stock market returns or prices through their effect on expected earnings/cash flows and/or discount rates (Apergis and Miller, 2009; Miller and Ratti, 2009). Oil price shocks affect cash flows through their effect on dampening demand for firm's products and also because they increase the costs of production. High oil prices can also adversely affect discount rate for cash flows through their effects on expected real interest rates and expected inflation (Miller and Ratti, 2009). This is because the stock price is the present value of expected future cash flows, discounted by the discount rate and movements in both expected cash flows and discount rates will affect stock returns (Mohanty et al., 2011).

The nature of the effect of oil shocks on cash flows depends on the firm's status as either a producer or consumer of oil. For firms whose output is oil, an oil price increase will increase cash flows while for those firms that use oil as an input cash flows will fall. Higher oil prices can lead to higher hurdle rates on investment and this can adversely affect the stock price (Mohanty et al., 2011). The implication of the above is that the exact nature of the effect of oil price increases on stock returns will depend on the net effect of movements in expected cash flow and expected discount rates and it is expected that this effect will be positive for net oil producers and negative for net oil consumers. For oil price decreases, it is expected that the direction of these effects will be converse.

There is no consensus in the empirical literature on the nature of the relationship between stock returns and oil prices. Early studies included Jones and Kaul (1996), Sadorsky (1999), and Papapetrou (2001). In more recent times, there has been an increased volume of research into this issue and studies include Hammoudeh and Choi (2006), Cong et al. (2008), Miller and Ratti (2009), Apergis and Miller (2009), Chiou and Lee (2009), Chen (2010), Narayan and Narayan (2010), Elyasiani et al. (2011), Arouri (2011), Lee and Chiou (2011), Masih et al. (2011), Mohanty et al. (2011), Zhang and Chen (2011) and Jammazi (2012).

\section{Exchange rates}

The first proposition regarding the relationship between exchange rates and stock performance was developed by Dornbusch and Fisher (1980) in 1980. According to Dornbusch and Fisher (1980), business sustainability and financial position of companies in an open economy will be directly affected by the turbulence in exchange rates. In detailed, an appreciation in exchange rate impairs the exporting competency of a country due to the fact that importing products from that particular country is more expensive. In opposite, a country facing depreciation in exchange rate will be more price-competitive in the international market since their products are cheaper. As a result, the appreciation might not be usually good for companies in an exporting country since stock performance could be negatively influenced by the change in exchange rates, vice versa (Kim, 2003).

However, the international trading effect proposed by Dornbusch and Fisher (1980) is theoretically unfitted in the portfolio balance model. Instead of causality running from exchange rates to stock performance, the proponents of the portfolio balance model suggested that stock prices are the key stimuli influencing the exchange rate (Frenkel, 1976; Branson, 1983; Macdonald and Taylor, 1992). When domestic share prices are rising, 
international investors will liquidize their foreign holdings to have a position in the domestic stock. To complete the transaction, international investors are required to buy domestic currency in exchange of their local currencies. Hence, domestic currency rate will be elevated against other currencies as a consequence of increases in domestic stock prices. In short, difference in direction of causality and the sign of magnitude disharmonize the theoretical fundamental pertinent to the relationship between exchange rates and stock performance.

Empirical researchers regarding the relationship between exchange rates and stock performance explicitly present a divergence in results. The possible earliest effort to investigate the relationship was conducted by Franck and Young (1972) who concluded that there is no observable association between exchange rates and stock performance. The second clue was provided by Aggarwal (1981) who found a positive correlation between the variables from the observations of U.S. dollar and movements in the U.S. stock indices. He highlighted that the international trading effect could be one of the plausible explanations to substantiate the presence of the relationship, while this result was supported by a later study conducted by Gionanini and Jorion (1987).

Following the model specification of GARCH, Najang and Seifert (1992) documented that fluctuation in exchange rates is derivative of movements in stock prices for Western countries. This result supported the portfolio balance model and disagreed with the international trading effect. Nevertheless, Ajayi and Mougoue (1996) concluded that depreciation in currency power has negative impacts on stock market in both the long and short run in the economy of G7. Mohamad and Mahmood (2001) also found that intraday returns of exchanges rates significantly cause the volatility of stock returns, and this magnitude does not present in the other way round in Malaysia over the period of 1997 to 1999. Thus, there is incongruence between the applicability of the international trading effect and the portfolio balance model in different examination contexts.

Albeit a number of researchers proved the empirical significance of two dominant conceptual frameworks, some researchers found a null relationship between exchange rates and stock performance. Bahmani-Oskooe and Sohrabian (1992) using cointegration analysis and found that there is no long run relationship between the variables, although the variables are bidirectional causally linked. Further, Solnik (1987), Chow et al. (1997) and Bhattacharya and Mukherjee (2003) found no both long run equilibrium and short run dynamics between exchange rates and stock prices in three different pairwise countries. Generally, there is no single theory or model to explain the relationship between the variables since incongruence in economic characteristics diverge one economy from another economy.

\section{Inflation}

Stock investment had conventionally been viewed as a good hedging instrument against price increment, or inflation, as shareholders has the right to claim return from physical asset whose real economic benefits are theoretically undisturbed by inflation (Lee, 2010). According to Fisher (1930), possible inflation in future will be fully incorporated in the contemporary changes in interest rates. Inflation should be uncorrelated with stock prices due to the presence of interest rates. In contrast to this general view, a great number of academicians concluded that there is a negative relationship between inflation and stock returns in the U.S. and other countries in the 1980s (Bodie, 1976; Jaffe and Mandelker, 1976; Nelson and Schwert, 1977; Fama and Schwert, 1977; Gultekin, 1983). 
Critics of the null inflation-stock relationship proposed the Fed model to explain the cause and effect between inflation and stock prices (Quayes and Jamal, 2008). The Fed model postulates that bonds and stocks are the main components of an individual's portfolio and these financial instruments are substitutable with each other in accordance to the changes in inflation. Generally, central banks would positively adjust the interest rate in commensurate with inflation to control the inflationary or deflationary pressure on the economy. Namely, inflationary prices would result in an increase in interest rates, vice versa. Hence, inflationary condition will increase the interest rate and the attractiveness of bond investment, while decrease the issuance of bond funding due to higher interest. Further, companies would try to use equities to replace the bond component in their capital structure. A series of increase in equities supply, decrease in bond supply and increase in bond attractiveness inflates bond prices at the expenses of stock prices. Therefore, inflation would cause stock prices moving downwards, or simple, inflation is negatively related to stock prices.

In recent, Gallgher and Taylor (2002) presented that inflation is negatively correlated with stock performance for the reason of supply shock, although demand shocks have little or insignificant impacts on this relationship. Rapach (2002) found no proof that inflation impairs the long-run real value of stock by investigating 16 developed countries. Although most empirical researches for developed economies indicated a negative relationship between inflation and stock performance, this relationship could not be true for emerging economies. Spyrou (2004) discovered that countries from Latin America and Asia show a positive relationship between the variable. Al-Khazali and Pyun (2004) showed that the relationship between inflation and stock returns is only limited to a short run, while these variables have a positive relationship in a long run.

\section{Interest rates}

According to Flannery and James (1984), the changes in interest rates are correlated with the intraday returns of the U.S. stock market indices. The effect of interest rates on stock performance is explained by the Fed model, which was discussed in the earlier part. Apart from the Fed model, Gordon and Shapiro (1956) and Gordon (1959) highlighted that interest rates, especially risk free rates, are parts of the discounting factors on valuing a stock. An increase in risk free rates will decrease the present value of future economic benefits. Although the explanations relating to the relationship between interest rates and stock returns are dissimilar in different theoretical frameworks, they generally believed a negative relationship between interest rates and stock returns. However, the capital asset pricing model does not agree with the negative relationship between the variables since an increase in risk free rates might simultaneously increase the hurdle rate of shareholder's requirement (Bodie et al., 2008; Chong et al., 2013). Thus, the attractiveness of bond investment due to increase in interest rates will be diluted by a later increase in stock returns in the long run.

Pertinent to the empirical relationship between interest rate and stock returns, Yohannes (1994) found a unidirectional causality from stock performance to interest rate by examining the Nigerian stock market. A long run relationship between government t-bill rates and stock performance was filed by Mukherjee and Naka (1995) under the specification of a vector error correction model. Soydemir (2000) found a negative impact of the U.S. t-bill rates on the U.S. stock market, and this relationship is also presenting in Latin America at a weaker significant degree. This negative relationship was proved to be true in the study by Al-Sharkas (2004). In short, the relationship between interest rates and stock performance is consistent in different studies, although the significance levels are various. 


\section{Theoretical Framework:}

Summarizing previous theoretical models and empirical findings provides this paper a constructive framework to examine the direction of causality and the presence of long-term relationship between stock market performance and those macroeconomic variables. A mere association between stock market performance and another variable (Duca, 2007) or a relationship established on the assumptions of a linear regression is insufficient to grant external users meaningful evidences to support their practical uses in applying those findings. Thus, this paper takes one step further over those previous studies to combine a number of supposedly significant macroeconomic variables to filter out the gross effect of each variable on the variation in stock market performance, and explore the influences of past innovations on the current variation in stock market performance by embedding economic growth, oil prices, exchange rates, inflation and interest rates.

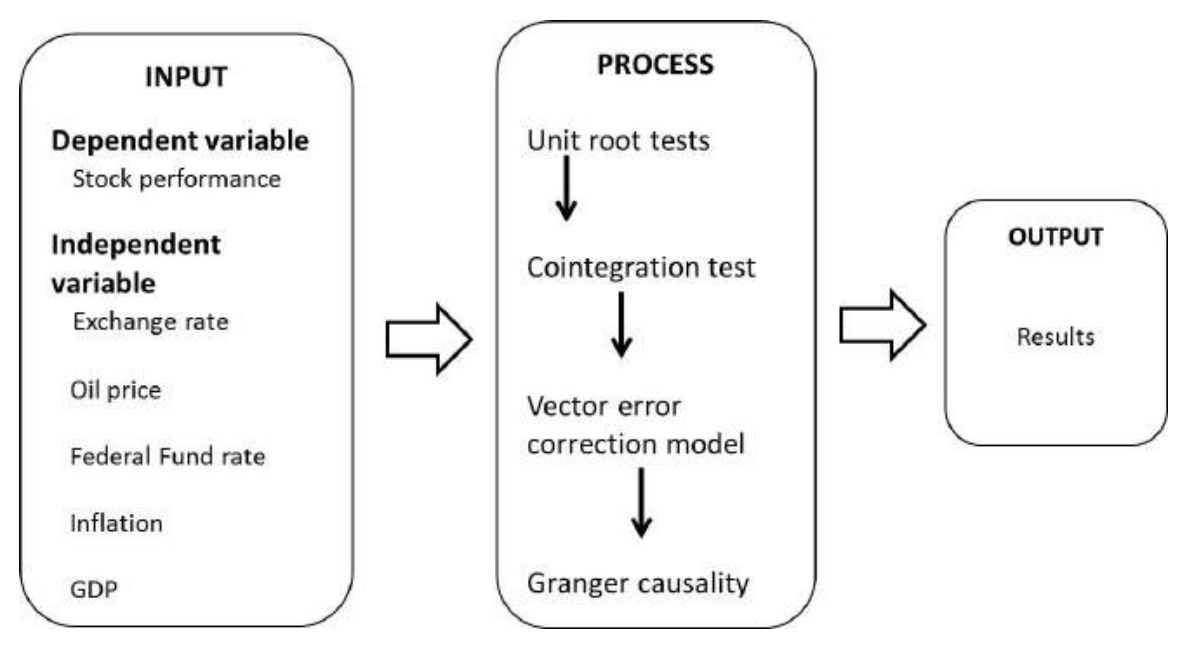

\section{Data collection}

\section{RESEARCH METHODOLOGY}

The EViews 7.2 is the software use to test the relationships in this paper. Eviews 7.2 can handle time-series-based multiple types of data, which include regression analysis, time series analysis and other basic traditional data analysis and the establishment of conditional heteroskedasticity, vector autoregression complex econometric models and so on.

To investigate the relationship, the paper handles the following tests. The Unit Root Test can estimate whether the time series is stationary. If the result is stationary, then the Cointegration Test (Johansen Test) will be processed whether there is a long-run relationship. If the result is cointegrated, a Granger causality test and a vector error correction model (VECM) will be handled to investigate short-run dynamics and long-run equilibrium between stock market performance, economic growth, living costs, exchange rates, risk-free rates and international oil prices in the research context of BRIC. Granger causality test(Granger, 1969), which is a statistical hypothesis test, and it was used to make sure that whether one time series can forecast another time series. VECM is a multi-factor model was used to test the deviation of the current state from its long-run relationship will be fed into its short-run dynamics. All secondary data pertinent to the causality between stock market performance and macroeconomic variables are collected from World Development Indicator and DataStream. Gross domestic products and inflation are used to measure BRIC's economic development (Bodie et al., 2008). Exchange rates, risk free rates and international oil prices are employed as the proxies of international spill over effects on 
BRIC's economies (Farnham, 2009). This paper adopts a quarterly basis on the data collection. The research time span of this paper is the period from 1996:Q4 to 2013:Q1. The main objective of this paper is to examine the causal relationship between stock performance and economic fundamentals, and can explore the homogeneity of explanatory variables in explain the variation in stock performance.

These variables are chosen as the explanatory variable of stock prices because of their theoretical and empirical association with stock prices movements. As mentioned in the section of literature review, economic growth provides an endogenous improvement for the stock investment platform and the stock market's supporting background. Elevation in economic growth implies an increase in companies' outputs, while better economic condition recursively benefit companies in the long run. Oil prices are the core cost component of almost all companies since transportation is the key trigger to inflation in an economy. The Fed model, international trading effect and Gordon growth model explain the impact of interest rate, exchange rate and inflation on stock returns. Generally, previous studies present mixed results regarding the relationship between the variables. However, if the Efficient Market Hypothesis works, none of the lagged explanatory variable will be significant on quarterly stock returns. This paper attempts to figure out the key theory or conceptual framework of explaining the main stimuli of stock performance in BRIC.

\section{Model specification Unit root tests}

According to Engle and Granger (1987), the presence of a unit root might impair the validity of research outputs. To deal with this issue, this paper simultaneously applies three unit root tests on the task of examining the stationarity properties within the time series of all variables. Applying a stationarity test prevents this research from the issue of inferring wrong data analyses pertinent to the causal relationship between stock market performance and macroeconomic variables (Granger and Newbold, 1974; Engle and Granger, 1987). This paper uses the Augmented Dickey-Fuller (Dicket and Fuller, 1981), Phillips-Perron (Phillips and Perron, 1988) and KPSS tests (Kwiatkowski et al., 1992) investigating the stationarity properties of all the variables. A Schwarz information criterion (maximum lags $=5$ ) is adopted as the principle of selecting the number of lagged term of the Augmented Dickey Fuller test. A Newey and West data-based automatic bandwidth parameter method is used to choose the bandwidth of the Phillips Perron and KPSS tests. Null hypothesis of the Augmented Dickey Fuller and Phillips-Perron tests are that there is a unit root within the examined time series. Rejection of the null hypothesis is necessary to investigate the slope coefficient of one variable to another variable. As the null hypothesis of the KPSS test is opposite to another two unit root tests, it provides a good complementary effect on the evaluation of unit root within a time series.

This paper examines the time series under the measurements of both levels and first differences because economic variables are usually not stationary at levels but stationary at first differences (Perron, 1989). The integration order of the variables can be expressed from the comparison between the level approached and first differenced approach among the variables. A precise integration order is essential for the cointegration test since the Johansen cointegration test is only suitable for the content of first differenced series.

\section{Cointegration test}

Keeping in view the theoretical postulates of the relationship between stock performance and macroeconomic variables, the model has been specified as follows: 


$$
\ln \mathrm{SP}=f(\ln \mathrm{EG}, \ln \mathrm{OP}, \ln \mathrm{CP}, \ln \mathrm{TB}, \ln \mathrm{ER})
$$

where ln stands for natural logarithm; SP stands for stock performance or quarterly returns of BRIC's stock indices, EG, OP, CP, TB and ER are the set of macroeconomic variables which theoretically or empirically influences the variation in stock performance. EG, OP, CP, TB and ER are economic growth (GDP), oil price, inflation rate, the Federal Reserve fund rate and the local currency exchange rate against the USD, respectively.

If the variables are proved to be cointegrated at first differences, or integrated of the order of 1 , this paper may proceed to the adoption of the Johansen (1991) cointegration test for examining the long run equilibrium among stock market performance, GDP, inflation, exchange rates, risk-free rates and international oil prices. According to the Granger representation theorem, the vector $X_{t}$ has a vector autoregressive error correction representation in the following specification (Alam and Huylenbroeck, 2011):

$$
\Delta X t=\prod X_{t-1}+\sum_{i=1}^{k-1} \Gamma i \Delta X t-i+\Phi D_{t}+\omega_{t}
$$

where,

$\Pi=\sum_{i=1}^{p} A i-1$ and $\Gamma i=-\sum_{j=i+1}^{p} A j X t$ is a $\left(X^{*} 1\right)$ dimension vector corresponding to the number of the variables (SP, EG, OP, CP. TB and ER), in which those variables are integrated of the first differenced order. This model will estimate the parameter matrices, which are $\Pi$, $\Gamma_{i}$ and $\Phi . D_{t}$ is a vector with deterministic elements (intercept and trend) and $\omega_{t}$ is a error term that follows the assumptions of white noise and homoscedasticity. In order to sophisticatedly examine the cointegrating relationship among the variables in terms of the linear and quadratic trends, this paper applies the Johansen maximum likelihood method (Johansen, 1988; Johansen and Juselius, 1990). To select the optimal model for testing the significance of the cointegrating vector among the variables, this paper follows the model selection rules from Osterwald-Lenum (1992). The step is essential to observe whether restriction in intercept and the presence of a time trend is significant in testing the cointegrating relationship.

The Johansen cointegration test is used to measure the $\prod$ matrix from an unrestricted vector autoregressive model and to test whether a reduction in rank $\prod$ would cause a rejection on the cointegration properties among the variables. The reduced rank (П) is primarily investigated by the trace test and maximum eigenvalue. When the number of exclusive cointegrating vector ( $r$ ) is less than or equal to the cointegration vector from a general alternative, the trace statistics' null hypothesis is said to be not rejected. The maximal eigenvalue examines the significance that compares the number of cointegrating vector against the alternative with additional one unit in the cointegrating vector. When both the trace statistic and maximum eigenvalue statistic are larger than the MacKinnon-HaugMichelis (1999) critical values, the null hypothesis of cointegrating $r$ vectors against the vector of alternative is rejected.

\section{Error correction model and Granger causality}

If there is a long-run relationship among the variables, this paper will apply the Granger causality approach under a vector error correction modeling framework for documenting the short-run dynamics among the variables. The presence of cointegration among the variables suggests that there is at least unidirectional (could be bidirectional as well) longrun Granger causality from endogenous variables to dependent variables (Mosconi and 
Giannini 1992; Dolado and Lutkepohl, 1996). The error correction model for investigating the relationship among variables is:

$$
\begin{aligned}
& \Delta S P_{t}=\mu+\sum_{i=1}^{k 1} \beta i \Delta S P t-1+\sum_{j=1}^{k 2} \beta j \Delta E G t-1+\sum_{l=1}^{k 3} \beta l \Delta O P t-1+\sum_{m=1}^{k 4} \beta m \Delta C P t-1 \\
& +\sum_{n=1}^{k 5} \beta n \Delta T B t-1+\sum_{o=1}^{k 6} \beta o \Delta E R t-1+\alpha E C T_{t-1}+\varepsilon
\end{aligned}
$$

where ECT is an error correction terms which examines the long-run equilibrium among the variables. If ECT is significant in the model, the set of explanatory variables will have explanatory power on dissecting the variation in stock market performance in the long run for BRIC.

This paper also applies the pairwise Granger causality test to investigate the direction of causality among the variables. The pairwise bivariate model of estimating causality between the variables are:

$$
\begin{aligned}
& S P_{t}=\mu_{1}+\sum_{i=1}^{l} \alpha 1 i E G t-1+\sum_{i=1}^{l} \beta 1 i S P t-1+e_{1 t} \\
& E G_{t}=\mu_{2}+\sum_{i=1}^{l} \alpha 2 i S P t-1+\sum_{i=1}^{l} \beta 2 i E G t-1+e_{2 t}
\end{aligned}
$$

where EG can be substituted by the other explanatory variables for investigating the presence of Granger causality from the explanatory variables to stock market performance. $\mu$ is a deterministic component (intercept) and $e$ is white noise to the model. All variables are presented in the form of first differences in the pairwise Granger causality test. The lag length is selected by the Akaike Information Criterion since the number of observations is less than 60 (Liew, 2004). Null hypothesis of the Granger causality test is that there is no Granger causality between a pair of variables. Rejection of the null hypothesis suggests that the lagged terms of an independent variable are able to explain the variation in dependent variable at the presence of all influential past information from the dependent variable. The Granger causality equations are applicable for all the variables for examining pairwise Granger causality between stock market performance and the sole explanatory variable.

\section{FINDINGS}

Table 1 tabulates the results of the Augmented Dickey-Fuller, Phillips-Perron and KPSS unit root tests. All unit root test equations are tested under the specification of an intercept but no time trend.

The inclusion of a time trend estimate generates no significantly different results. The test statistics indicate that most first differenced data series are significant at the $1 \%$ level under the Augmented Dickey-Fuller and Phillips-Perron tests. In contrast, most data series in levels are not significant even at the loosest condition, which is the $10 \%$ significance level. The KPSS test results are generally consistent with the test statistics of the Augmented DickeyFuller and Phillips-Perron tests. According to Perron (1989), most of the macroeconomic variables are stationary at first difference despite the stationarity properties are absent at levels for the same set of macroeconomic variables.

Albeit there are few variables significant at levels, this condition does not prevent this paper from adopting any first-difference-based cointegration test to observe the cointegration properties among the variables. This is because the unit root tests show that all variables for BRIC are generally integrated of the first order. Thus, the cointegration properties among the variables are investigated under the Johansen cointegration test, which is a first differenced based cointegration test. 


\section{Table 1: Unit root tests}

\begin{tabular}{|c|c|c|c|c|c|c|}
\hline \multirow[t]{2}{*}{ Variables } & \multicolumn{2}{|c|}{$\mathrm{ADF}$} & \multicolumn{2}{|c|}{ PP } & \multicolumn{2}{|c|}{ KPSS } \\
\hline & Level & $\begin{array}{c}\text { First } \\
\text { difference }\end{array}$ & Level & $\begin{array}{c}\text { First } \\
\text { difference }\end{array}$ & Level & $\begin{array}{c}\text { First } \\
\text { difference }\end{array}$ \\
\hline \multicolumn{7}{|l|}{ Brazil } \\
\hline Stock & $-1.5533[0]$ & $-7.5083[0]^{* * *}$ & $-1.5577[1]$ & $-7.4937[3]^{* * *}$ & $1.0027[6]^{* * *}$ & $0.1112[2]$ \\
\hline Exchange & $-2.1606[0]$ & $-6.6159[0]^{* * *}$ & $-2.1601[5]$ & $-6.5211[8]^{* * *}$ & $0.2763[6]$ & $0.3368[5]$ \\
\hline GDP & $0.6892[0]$ & $-6.2778[0]^{* * *}$ & $0.5327[2]$ & $-6.2433[3]^{* * *}$ & $1.0402[6]^{* * *}$ & $0.1947[2]$ \\
\hline Inflation & $-0.3109[2]$ & $-5.1909[1]^{* * *}$ & $-0.4484[3]$ & $-4.4584[7]^{* * *}$ & $1.0544[6]^{* * *}$ & $0.1483[3]$ \\
\hline \multicolumn{7}{|c|}{$\begin{array}{l}\text { - - - - - - - - - - - - - - - - - - - - - - - - - - - - - - - - - - - - - - - - - - - - - - - - - - - } \\
\text { Russia }\end{array}$} \\
\hline Stock & $-1.6661[1]$ & $-6.5717[1]^{* * *}$ & $-1.4797[1]$ & $-5.5769[4]^{* * *}$ & $0.8944[6]^{* * *}$ & $0.0733[0]$ \\
\hline Exchange & $65.58[5]^{* * *}$ & $-4.4494[3]^{* * *}$ & $-3.7296[8]^{* * *}$ & $-8.1063[6]^{* * *}$ & $0.3804[5]^{*}$ & $0.2367[6]$ \\
\hline GDP & $0.4484[0]$ & $-8.3596[0]^{* * *}$ & $0.3905[4]$ & $-8.3986[4]^{* * *}$ & $1.0570[6]^{* * *}$ & $0.1632[4]$ \\
\hline Inflation & $1.4614[5]$ & $-3.7626[5]^{* * *}$ & $1.8949[8]$ & $6.3578[10]^{* * *}$ & $0.9588[6]^{* * *}$ & $0.3454[3]$ \\
\hline \multicolumn{7}{|c|}{$\begin{array}{l}\text { India } \\
\text { In }\end{array}$} \\
\hline Stock & $-0.6214[0]$ & $-7.7413[0]^{* * *}$ & $-0.6214[0]$ & $-7.7443[2]^{* * *}$ & $0.9752[6]^{* * *}$ & $0.0762[1]$ \\
\hline Exchange & $\begin{array}{c}-2.3175[4] \\
-\end{array}$ & $-5.2441[3]^{* * *}$ & $-2.0336[3]$ & $\begin{array}{c}-7.5753[3]^{* * *} \\
-\end{array}$ & $0.5372[6]^{* *}$ & $0.0864[3]$ \\
\hline GDP & $2.9591[4]^{* *}$ & $-2.6459[5]^{*}$ & $4.1841[60]^{* * *}$ & $6.8714[42]^{* * *}$ & $1.0033[6]^{* * *}$ & $0.3660[12]^{*}$ \\
\hline Inflation & $1.7058[0]$ & $-2.4741[3]^{*}$ & $1.6757[5]$ & $-6.7460[5]^{* * *}$ & $1.0375[6]^{* * *}$ & $0.4338[1]^{*}$ \\
\hline \multicolumn{7}{|c|}{$\begin{array}{l}\text { - - - - - - - - - - - - - - - - - - - - - - - - - - - - - - - - - - - - - - - - - - - - - - - - - - - } \\
\text { China }\end{array}$} \\
\hline Stock & $-2.4427[1]$ & $-6.0020[0]^{* * *}$ & $-2.4653[3]$ & $-6.0020[0]^{* * *}$ & $0.6367[6]^{* * *}$ & $0.0833[2]$ \\
\hline Exchange & $0.3596[1]$ & $-3.4321[0]^{* * *}$ & $1.0283[8]$ & $-3.4495[2]^{* * *}$ & $0.8936[6]^{* * *}$ & $0.4435[5]^{*}$ \\
\hline GDP & $0.5564[5]$ & $-2.5776[4]^{* * *}$ & $-0.7996[13]$ & $28.627[12]^{* * *}$ & $1.0518[6]^{* * *}$ & $0.2532[11]$ \\
\hline Inflation & $-0.3109[2]$ & $-5.1909[1]^{* * *}$ & $-0.4484[3]$ & $-4.4584[7]^{* * *}$ & $1.0544[6]^{* * *}$ & $0.1483[3]$ \\
\hline \multicolumn{7}{|c|}{ 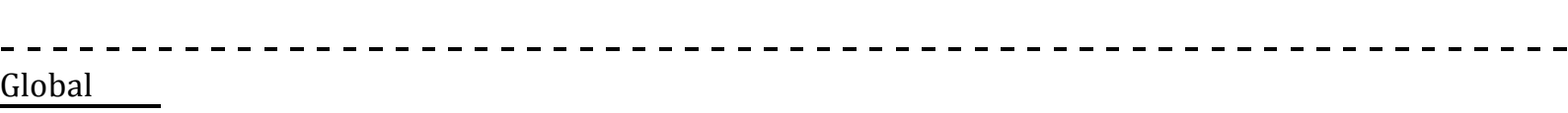 } \\
\hline Oil & $-0.9855[0]$ & $-7.8991[0]^{* * *}$ & $-0.8044[5]$ & $-8.1383[6]^{* * *}$ & $0.9788[6]^{* * *}$ & $0.0858[6]$ \\
\hline Interest & $-0.6323[0]$ & $-7.9546[0]^{* * *}$ & $-0.6526[3]$ & $-7.9541[3]^{* * *}$ & $0.7469[6]^{* * *}$ & $0.1106[3]$ \\
\hline
\end{tabular}

The test statistics shown in Table 2 suggest that the hypothesis of no cointegration among the variables is rejected at the $1 \%$ significance level. This indicates that there is at least one cointegration vector among the variables for BRIC. According to Engle and Granger (1987), the presence of one or more significant linear combinations between the variables indicates that those non-stationary variables are cointegrated. Since the examined variables are cointegration, these variables are subject to a long-run relationship which drifts the frictions of the variables back to an equilibrium level. The result from the Johansen cointegration test confirms that there is long run equilibrium among the variables for BRIC under both the trace statistics and maximum eigenvalue approaches. Therefore, a cointegrating relationship will be served as the basis for the error correction model pertinent to investigating the relationship among the variables. 
Table 2: Results of Johansen's cointegration test

\begin{tabular}{|c|c|c|c|c|c|c|c|}
\hline \multicolumn{8}{|c|}{ Trace statistics } \\
\hline & $r=0$ & $r \leq 1$ & $r \leq 2$ & $r \leq 3$ & $r \leq 4$ & $r \leq 5$ & Lag \\
\hline Brazil & $132.03^{* * *}$ & $73.172^{* *}$ & 41.563 & 22.219 & 5.97 & 0.725 & 2 \\
\hline Russia & $142.63^{* * *}$ & $86.028^{* * *}$ & $56.806^{* * *}$ & 30.118 & 12.644 & 1.407 & 2 \\
\hline India & $117.92^{* * *}$ & $73.064^{* *}$ & 44.113 & 19.993 & 3.329 & 0,0544 & 2 \\
\hline China & $189.46^{* * *}$ & $77.164^{* *}$ & 47.195 & 24.938 & 11.949 & 0.419 & 2 \\
\hline \multicolumn{7}{|c|}{ Maximum Eigenvalue statistics } & Lag \\
\hline & $\mathrm{r}=0$ & $r \leq 1$ & $r \leq 2$ & $r \leq 3$ & $r \leq 4$ & $r \leq 5$ & \\
\hline Brazil & $58.855^{* * *}$ & 31.609 & 19.354 & 16.239 & 5.245 & 0.725 & 2 \\
\hline Russia & $56.598^{* * *}$ & 29.222 & 26.688 & 17.473 & 11.237 & 1.407 & 2 \\
\hline India & $44.857^{* *}$ & 28.951 & 24.12 & 16.663 & 3.274 & 0.054 & 2 \\
\hline China & $112.30^{* * *}$ & 29.969 & 22.257 & 12.257 & 11.53 & 0.419 & 2 \\
\hline \multicolumn{8}{|c|}{$\begin{array}{l}\text { Notes: }{ }^{* *} \text { and }{ }^{* * *} \text { indicate } 5 \% \text { and } 1 \% \text { levels of significance, respectively. } \mathrm{r} \text { is cointegration } \\
\text { rank }\end{array}$} \\
\hline
\end{tabular}

Table 3 summarizes the contemporaneous effects among the variables under the examination specification of an error vector correction model. The proxy of global oil price is significant to impact the variation in stock performance for Brazil, India and China over the research time span of 1996:Q1 to 2013:Q1. Since Russia is one of the largest net energy exporters, it does have strong oil reserve to fulfil its local demands. The volatility properties of oil prices majorly influence the mechanism stability of energy importing countries, such as India (Srnivasan, 2012). The findings imply that the energy security does impact the variation in stock performance of developing country (Filis, 2010), although the oil exported could be free from this constraint.

Apart from that, economic growth mainly influences the countries that have no past experiences of practicing the communism authority, such as Brazil and India. When the policy of open economy or lasses-faire is not realized by a country, stock market performance of a country is generally believed to be self-reinforced (Stern, 2007). This condition can be substantiated by the feedback effect or autoregressive function of lagged stock performance to the current variation in stock market performance in Russia. Although this phenomenon is not explicitly significant, it does provide the Granger causality analysis a conceptual framework on investigating pairwise causality among the variables. 
Table 3: Results of vector error correction model

\begin{tabular}{lcccc}
\hline & \multicolumn{3}{c}{ Coefficients } \\
\cline { 2 - 4 } & Brazil & Russia & India & China \\
\hline Constant & 0.1097 & -0.0262 & 0.0333 & 0.0465 \\
$\Delta \mathrm{SP}(-1)$ & 0.1831 & $0.3697^{* * *}$ & 0.0218 & 0.1238 \\
$\Delta \mathrm{SP}(-2)$ & -0.0776 & $-0.3031^{* * *}$ & -0.0484 & 0.1433 \\
$\Delta \mathrm{OP}(-1)$ & -0.0965 & -0.0222 & $-0.2550^{*}$ & -0.2001 \\
$\Delta \mathrm{OP}(-2)$ & $0.3381^{*}$ & 0.0506 & $-0.3468 * *$ & $-0.2379 *$ \\
$\Delta \mathrm{TB}(-1)$ & 0.0064 & -0.0172 & 0.0588 & 0.0204 \\
$\Delta \mathrm{TB}(-2)$ & -0.0452 & 0.0106 & -0.0241 & 0.0119 \\
$\Delta \mathrm{EG}(-1)$ & $-4.2858 *$ & 1.8214 & $0.6011^{* *}$ & 0.0309 \\
$\Delta \mathrm{EG}(-2)$ & -0.3778 & 1.7038 & 0.1962 & 0.1157 \\
$\Delta \mathrm{ER}(-1)$ & -0.3144 & -0.0016 & -0.4845 & 1.3159 \\
$\Delta \mathrm{ER}(-2)$ & 0.1183 & 0.0126 & -0.5418 & 2.3338 \\
$\Delta \mathrm{CP}(-1)$ & -4.0546 & 0.3108 & -1.0666 & -1.1548 \\
$\Delta \mathrm{CP}(-1)$ & 0.2014 & -2.3738 & -0.2883 & -0.2184 \\
ECT(-1) & -0.1203 & -0.3112 & -0.0817 & -0.0116 \\
\hline 1. Stock performance is the dependent variable of the proposed vector error correction \\
model.
\end{tabular}

Note that none of the error correction terms are significant in the current model specification. This issue was mentioned in the study of Pesaran et al. (2001) who suggested that the Johansen cointegration test is only applicable to variables purely cointegrating of the first differenced order. Thus, the following analysis of Granger causality does not apply the block causality approach under the error correction model for investigating pairwise Granger causality among the variables. Instead, a standard bivariate Granger causality approach is adopted.

Table 4 documents Granger pairwise causalities among the variables for the BRIC members. According to Caporale and Pittis (1997), any omission of plausible explanatory variable could impair the validity of a causality structure. As a robustness check, this paper performs the Granger causality test with a set of empirically proved explanatory variables to sophisticatedly investigate the causal relationship between stock market performance and the variables. In detailed, stock market performance $(S)$ is explained by the exchange rates $(E)$, economic growth $(G)$, inflation (C), risk free rates (I) and oil prices (O). This paper applies two lags as the optimal lag length on investigating Granger causality between the pairwise variables. 
Table 4: Granger causality test

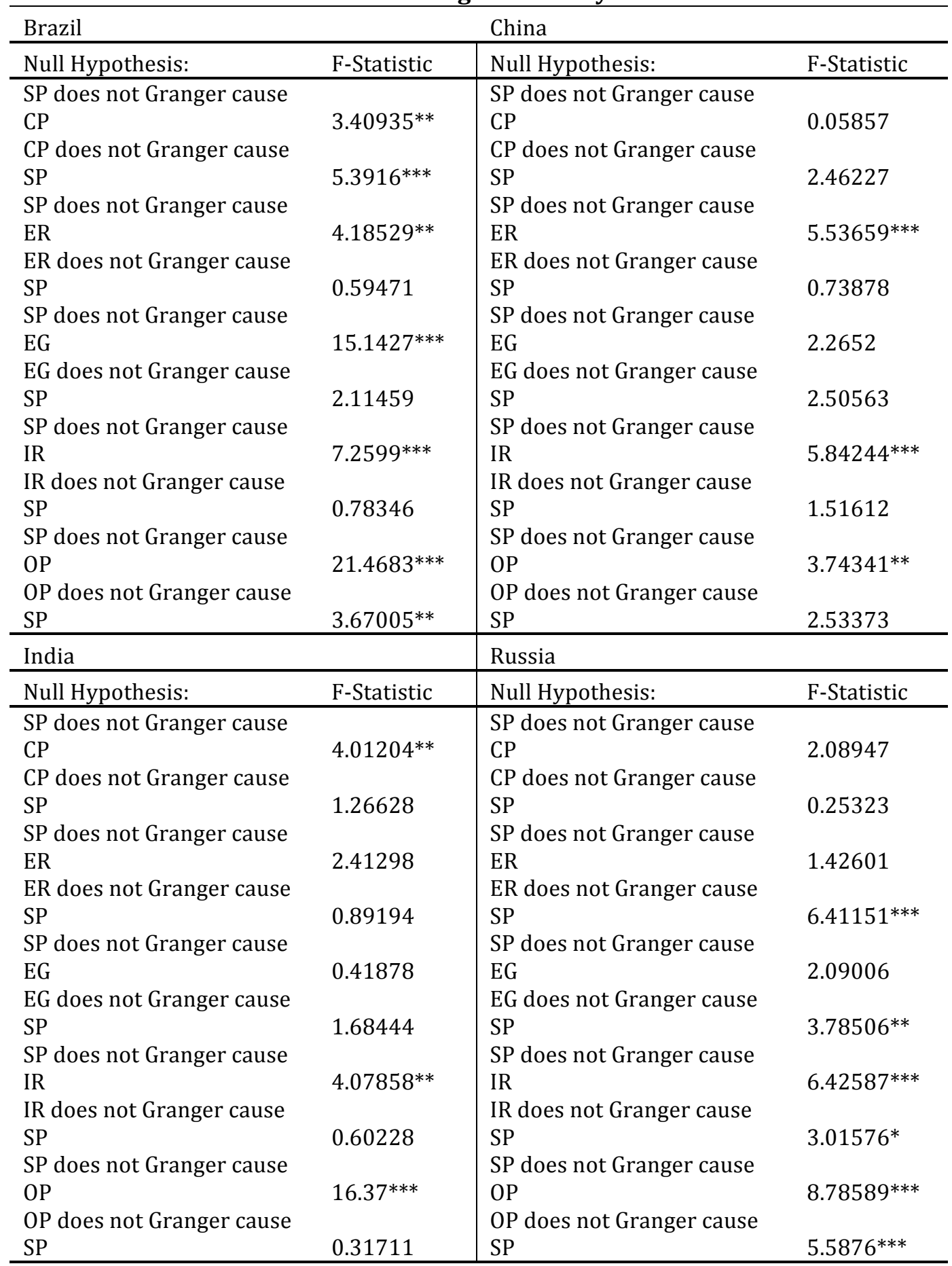

\section{Brazil}

The Brazilian stock market performance has a bilateral Granger causal relationship with the degree of inflation at the 5\% significance level in Brazil. This result is consistent with the findings of Benjamin (2008), who also reported that the Brazilian stock market performance is interlinked with the changes in inflation. This is because raw materials and primary products consist of around 50\% of the Brazilian exports. In comparison to processed goods, the prices of primary products are more susceptive to the impact of volatile inflation (Farnham, 2009). Narayan and Narayan (2010) claimed that oil prices could be significant in explaining the variation in stock performance for a developing country which relies on the receipts from the turnovers of raw materials and primary products. Since the Brazilian production structure is very similar to the theoretical background, it is unsurprising to 
document pairwise Granger causality between stock performance and inflation, and between stock performance international oil prices.

Moreover, the empirical findings indicate that the Brazilian stock performance does Granger cause economic growth, exchange rates and international risk free rates. Commonly, stock performance is dependent to the variation in macroeconomic variables (Valeriono and Lin, 1999). However, it is interesting to observe that the Brazilian stock market performance turns out to be the lead indicator of the macroeconomic variables. This situation is opposite to the findings of Benjamin (2008) in Brazil. A plausible explanation to the dissimilarity in results between this paper and previous study is that Brazil has experienced a structural change over the past 10 years and this rapid economic growth was not documented in the research of Benjamin (2008). The influx of foreign capitals and the great amount of hot money have switched the initial trigger of the domino effect from the macroeconomic variables to the stock market in Brazil. Brazilian high reliance on the foreign capital to finance its economy could be another explanation to elucidate this phenomenon (Samuelson, 2007). In other words, the sentiments of Brazilian social actors towards the Brazilian economy are triggered by the Brazilian investment climate at an above average level.

\section{India}

In contrast to Brazil, the Indian stock market performance has less explanatory power to Granger cause economic growth and exchange rates. Unilateral Granger causality from the stock performance to inflation in India implies that the investor sentiment in the Indian market is somewhat synchronized with the Indian spending behaviour (Shanmugam, 2003). Ray and Chatterjee (2001) claimed that this phenomenon could be a result of the foreign involvements on the Indian asset prices. Although the research time span is 10 years later than the preceding research, the empirical findings show that the causal relationship between stock performance and inflation is still consistent in India over time.

Besides, none of the macroeconomic variables is significant to Granger cause the Indian stock market performance. This situation suggests that the Efficient Market Hypothesis possibly exists in the Indian stock market, which was previously reported by Sharma and Mahendru (2009). This is because the variation in Indian stock performance could not be explained by the lagged value of any predefined macroeconomic variable. In general, the empirical findings from the Granger causality test are different from the research outputs of the vector error correction model. This result provides future researchers a proof that a difference in the model used could yield dissimilar results.

\section{China}

In consistent with the studies by Gabe et al. (2010), the findings of this paper also indicated that the Chinese stock market performance does Granger cause the Chinese economy. Gabe et al. (2010) provided the explanation that a liberalizing stock market improves the market liquidity of China and the Chinese asset price bubbles are usually correlated with booms in the Chinese stock market. Thus, liquidity provided from the Chinese stock market mechanism boosts the Chinese economy to grow beyond the sole support of local liquidity supply. However, this finding is opposite to the results of Jesus and Yue (2010), which stated that Chinese stock prices are determined by changes in domestic inflation, economic growth, short-term interest rates and the exchange rate.

None of the explanatory variables significantly Granger causes the stock movement in China. This deviation is possibly caused by differences in data frequency and the use of research 
time frame. For example, Jesus and Yue (2010) employed monthly data over the period of 1992 to 2008 whilst this paper adopts a quarterly data over the period of 1996 to 2013 in investigating the relationship between stock market performance and macroeconomic variables in China. Thus, the findings suggest that there is a change in the market phenomenon over the past few years, especially after the post-period of the Subprime Mortgage crisis.

\section{Russia}

The findings indicate that the exchange rate, economic growth, the U.S. Treasury Bill rate and international oil price do Granger cause the movements of stock prices in Russia. Previously, Alexie and Alexie (2006) and Stanislav (2006) have documented the effect of these variables on the Russian stock market. Generally, they did report a similar finding as the exchange rate, GDP, the risk free rate and oil prices are lead indicators to stock market performance in Russia. Thus, the Russian stock market behaviour is still stable and consistent over the past decade.

\section{Overall}

Overall, BRIC's stock markets significantly Granger cause the U.S. t-bill rates and international oil prices, while this is the only homogeneity among the examined countries. This result implies that BRIC's demands on risk free t-bill and oil supply are large enough to influence the variation in these two international macroeconomic variables. In simple, liquidity squeeze is presented in the international market on the matter of choosing the right decisions over all feasible investment instruments. Besides, economic growth is only significant to stock performance in Russia. Although no lagged term of those explanatory variables is significant in explaining the variation of stock market performance for China and India, this paper is unable to conclude anything relating to the generalisability of the Efficient Market Hypothesis in these markets. The result only indirectly implies that a quarter is adequate enough for BRIC's stock market incorporating the information of those macroeconomic variables.

Generally, the changes in exchange rates, risk free rates and inflation do not Granger cause BRIC's stock market performance. Namely, the international investment atmosphere only has little spillover effect on BRIC. The Fisher effect regarding the null relationship between inflation and stock performance is a more relevant theory than the Fed model and the portfolio balance model on understanding the market behaviour of BRIC. Although there is no general guide of choosing macroeconomic indicators for the forecasting of stock prices, one should follow the economic and financial theories in modelling the endogenous variable of stock price movements.

\section{Summary}

\section{CONCLUSION}

The primary objective of this study is to revisit the causal relationship among stock market performance and macroeconomic variables under the research context of BRIC. The objectives of this paper are investigated via the means of unit root tests, cointegration test and the Granger causality approach over the period from 1996:Q4 to 2013:Q1. A unit root test was used to examine the stationarity properties within the time series of all variables. The Johansen cointegration test (1991) is used to measure the $\Pi$ matrix from an unrestricted vector autoregressive model and to test whether a reduction in rank $\prod$ would cause a rejection on the cointegration properties among the variables, which was used to test whether there is a long-run relationship. The Granger causality test (Granger, 1969) is a statistical hypothesis test, and it was used to make sure that whether one time series can forecast another time series. The results indicate that there is a cointegrating relationship 
among the variables and a long run equilibrium relationship is existent among stock market performance, economic growth, inflation, exchange rates, risk-free rates and oil prices for the BRIC.

Overall, the results from BRIC present dissimilar results against previous studies regarding the relationship among stock market performance and macroeconomic variables. The impacts of socialism and capitalism do not effectively categorise the effects of macroeconomic variables into BRIC's stock market performance. However, it is interesting to see that BRIC's stock market performances do significantly Granger cause the U.S. Treasury Bill rate and international oil prices. Namely, the lagged terms of stock prices do jointly impact the variations in international risk-free rates and oil prices. Commonly, previous researchers reported that risk-free rates and oil prices are the deterministic variables of stock prices (Christiano et al., 2011; Jesus and Yue, 2011; Fabia and Andre, 2009; Nathan and Mark, 2005). A reserve relationship from BRIC's stock market performance to international variables indicates that the purchasing capacities of BRIC are considerable to influence the international demand and supply in the U.S. t-bill investments and oil products. Since previous studies did not apply a Granger causality test on this relationship, a divergence between the findings does not oppugn the validity of this study. More detailed, vibrant economic performance of the BRIC signifies BRIC's importance in the global market.

Conclusively, the results document a weak significance from the macroeconomic variables to BRIC's stock market performance. This paper yields very little evidences to generalise the theoretical framework regarding the relationship among stock market performance and macroeconomic variables. The Efficient Market Hypothesis is not considerably challenged by the results of this paper. This is because most of the quarterly lagged terms of macroeconomic variables have no impact on stock market performance of BRIC. For example, highly dynamic variables, such as exchange rates and interest rates, do not Granger cause the movements of stock prices in a quarterly lagged term. The null impact of inflation on stock performance is proved to be existent in this study. The effect of inflation could be absorbed by the interest rate as suggested by previous researchers. However, the Fed model and the portfolio balance model are not applicable to BRIC since this paper documents no constructive impacts from exchange rate and interest rate to stock performance in a long run.

\section{IMPLICATIONS OF FINDINGS}

The results of this study provide readers several constructive insights in political and financial outlooks. First, all macroeconomic variables examined in this paper are significant to construct a long-run relationship with stock market performance (as reported in the Johansen cointegration test), although the short-run dynamics among the variables are relatively weak to in comparison to the significance of the long-run relationship (as reported in VECM). A weak short-run relationship following a significant long-run relationship indicates that the efficient market hypothesis is still effective to infer the condition of BRIC's stock market mechanisms. In other words, the impacts of temporary frictions (financial crises or economic events) are not really influential to the stock markets of BRIC. Since market efficiency is the key to promote a good stock market structure, BRIC's government should let their stock markets remain the current condition for a laissez-faire purpose.

With respects to investors, the results suggest that they are unlikely to exploit a consistent in-money position in BRIC's stock market via the use of fundamental macroeconomic analysis. Although economic growth has realistically contributed to booming in BRIC's stock 
markets, actual components of economic growth that facilitate the booming is still unidentified in this paper. Although some variables Granger cause stock performance in Brazil and Russia in a short run, investor should not blindly use those variables as a rule of thumb in investment. Further investigation is required to minimize investors' exposure to stock market volatility.

\section{RECOMMENDATIONS}

To advance the research regarding this relationship, future researchers are advised to adopt the autoregressive distributed lag model (ARDL) to examine the long-run equilibrium among the variables. This is because the ARDL model can effectively deal with the issues of small sample size and I(1)/I(0). More importantly, a universal lag applied on all explanatory variables could not fully express the lagged effect of one variable to stock market performance. For example, stock market might take one lag (one quarter) to absorb the impact of economic growth, while it could spend two to three lags reflecting the impact of the risk free rates in the stock market. Thus, the ADRL model could be superior to the Johansen cointegration test in examining the long-run relationship among the variables. Further, different frequencies and subdivided examination windows should be adopted to observe the revolutionary progress of the relationship among the variables.

\section{References}

Aggarwal, B. (1981) 'Exchange rates and stock prices: a study of the United States capital markets under floating exchange rates'. Akron Business and Economic Review, Vol. 12, pp. 7-12.

Ajayi, R. and Mougoue, M. (1996) 'On the dynamic relation between stock prices and exchange rates'. Journal of Financial Research, Vol. 19, pp. 193-207.

Alam, M.J. and Huylenbroeck, G.V. (2011) 'Energy consumption, Co2 emissions and the economic growth nexus in Bangladesh: Cointegration and dynamic causality analysis'. AAS-ICAS Joint Conference.

Al-Khazali, O.M. and Pyun, C.S. (2004) 'Stock prices and inflation: New evidence from the Pacific-basin countries'. Review of Quantitative Finance and Accounting, Vol. 22, pp. 123-140.

Al-Sharkas, A. (2004) 'The Dynamic Relationship Between Macroeconomic Factors and the Jordanian stock market'. International Journal of Applied Econometrics and Quantitative Studies, Vol. 1, No. 1, pp. 97-114.

Apergis, N. and Miller, S.M. (2009) ‘Do structural oil-market shocks affect stock prices?'. Energy Economics, Vol. 31 , pp. $569-575$.

Arouri M.E.H. (2011) 'Does crude oil move stock markets in Europe? A sector investigation'. Economic Modelling, Vol. 28, No. 17, pp. 16-25.

Atje, R. and Jovanovic, B. (1993) 'Stock markets and development', European Economic Review, Vol. 37, pp. 632640.

Bahmani-Oskooe, M., Sohrabian, A. (1992) 'Stock prices and the effective exchange rate of the dollar', Applied Economics, Vol. 24, pp. 459-464.

Batten, J.A., Ciner, C. and Lucey, B.M. (2010) 'The Macroeconomic determinants of volatility in precious metals markets'. Recourses Policy.

Beck, T. and Levine, R. (2001) 'Stock markets, banks, and growth: Correlation or causality?'. World Bank Policy Research, Working Paper, No. 2670.

Bencivenga, V.R and Smith, B.D (1991) 'Financial intermediation and economic growth'. Review of Economic Studies, Vol. 58, No. 2, pp. 195-209.

Benjamin, A.A. (2008) 'Empirical relationship between macroeconomic volatility and stock returns: Evidence from Latin American markets', International Review of Financial Analysis, Vol. 17, pp. 395-410.

Bernanke, B. and Gertler, M. (1989) 'Agency costs, net worth and business fluctuations', American Economic Review, Vol. 79, No. 1, pp. 14-31. 
Bhattacharya, B. and Mukherjee, J. (2003) 'Causal relationship between stock market and exchange rate. Foreign exchange reserves and value of trade balance: A case study for India'. Fifth Annual Conference on Money and Finance in the Indian Economy.

Bilson, M.C., Brailsford, J.T. and Hooper, J.V. (2001) 'Selecting macroeconomic variables as explanatory factors of emerging stock market returns'. Pacific-Basin Finance Journal, Vol. 9, No. 4, pp. 401-426.

Binswanger, M. (2004) 'Stock returns and real activity in the G-7 countries: did the relationship change in the early 1980s?'. Quarterly Review of Economics and Finance, Vol. 44, pp. 237-252.

Blackburn, K., Bose, N. and Capasso, S. (2005) 'Financial development, financing choice and economic growth'. Review of Development Economics, Vol. 9, No. 2, pp. 135-149.

Bodie, Z. (1976) 'Common stocks as a hedge against inflation'. Journal of Finance, Vol. 31, pp. 459-470.

Bodie, Z., Kane, A. and Marcus, A.J. (2008) Investments, $7^{\text {th }}$ edition (International), McGraw-Hill: Boston.

Borges, M.R. (2008) 'Efficient market hypothesis in European stock markets'. Technical University of Lisbon, working paper.

Branson, W.H. (1983) 'Macroeconomic determinants of real exchange rate'. Cambridge University Press, Cambridge University.

Campbell, J. and Shiller, R.J. (1988) 'Stock prices, earnings, and expected dividends'. Journal of Finance, Vol. 43, pp. 661-676.

Celis, E.E. and Leow J.S. (2015) 'Political Cycle Stock Market- The Case of Malaysia”, Journal of Emerging Issues in Economics, Finance and Banking, Vol 4 Issue 1 pp.1468-1469.

Chen S.S. (2010) 'Do higher oil prices push the stock market into bear territory?'. Energy Economics, Vol. 32, pp. 490-495.

Chen, N.F., Roll, R. and Ross, S.A. (1986) 'Economic forces and the stock market'. Journal of Business, Vol. 59, No. 3, pp. 383-403.

Chiou J.S. and Lee Y.H. (2009) 'Jump dynamics and volatility: oil and the stock markets'. Energy, Vol. 34, pp. 788-796.

Chong, J., Jin, Y. and Phillips, M. (2013) 'The entrepreneur's cost of capital: Incorporating downside risk in the buildup method', Abstract from URL: http://www.macrorisk.com/wp-content/uploads/2013/04/MRA-WP2013-e.pdf

Chow, E.H., Lee, W.Y. and Solt, M.S. (1997) 'The exchange rate risk exposure of asset returns'. Journal of Business, Vol. 70, pp. 105-123.

Collins, D.W. and Hribar, P. (2000) 'Earnings-based and accrual-based market anomalies: one effect or two?'. Journal of Accounting and Economics, Vol. 29, No. 1, pp. 101-123.

Cong R.G., Wei Y.M., Jiao J.L. and Fan Y. (2008) 'Relationships between oil price shocks and stock market: an empirical analysis from China'. Energy Policy, Vol. 36, No. 35, pp. 44-53.

Cooray, A. (2003) 'the random walk behavior of stock prices: a comparative study", Discussion Pape.

Cootner P. (1962) 'Stock prices: Random vs. systematic changes”, Industrial Management Review, No.3, No. 2, pp. 24-45.

Daniel, K. and Titman, S. (2012) 'Testing factor-model explanations of market anomalies', Critical Finance Review, No.1, pp. 103-139.

Demirguc-Kunt, A. and Vojislav M. (1998) 'Law, finance, and firm growth'. Journal of Finance, Vol. 53, pp. 21072137.

Dickey, D. A. and Fuller, W. A. (1979) 'Distribution of the estimators for autoregressive time series with a unit root', Journal of the American Statistical Association, Vol. 74, No. 366, pp. 427-431.

Dimson, E. and Mussavian, M, (2000) 'Market efficiency', The Current State of Business Discipline, Vol. 3, pp. 959970. 
Dolado, J. and Lutkepohl, H.S. (1996) 'Making Wald tests for cointegrated VAR systems. Econometric Reviews, Vol. 15, No. 4, pp. 369-386.

Dornbusch, R. and Fisher, S. (1980) 'Exchange rates and current account'. American Economic Review, Vol. 70, pp. 960-971.

Duca, G. (2007) 'The relationship between the stock market and the economy: Experience from international financial markets', Bank of Valletta Review, No. 36, pp.1-12.

Elyasiani, E., Mansur, I. and Odusami, B. (2011) 'Oil price shocks and industry stock returns'. Energy Economics, Vol. 33, pp. 966-974.

Engle, R.F and Granger, C.W.J. (1987) 'Cointegration and Error Correction: Representation, Estimation and Testing'. Econometrica, Vol. 55, No. 2, pp. 251-276.

Evans, J. L. (1968) 'The random walk hypothesis, portfolio analysis and buy-and-hold strategy'. Journal of Financial and Quantitative Analysis, Vol. 3, No. 3, pp. 327-342.

Fama, E. F. (1965) 'The behavior of stock-market prices’. The Journal of Business, Vol. 38, No. 1, pp. 34-105.

Fama, E. F. (1970) 'Efficient capital market: A review of theory and empirical work'. Journal of Finance, Vol. 25, No. 2, pp. 383-417.

Fama, E. F. (1991) 'Efficient capital market: 2'. Journal of Finance, Vol. 46, No. 5, pp. 1575-1617.

Fama, E. F. (1995) ‘Random walk in stock market prices'. Financial Analysts Journal, Vol. 51, No. 1, pp.75-80.

Fama, E. F. (1998) 'Market efficiency, long-term returns, and behavioral finance'. Journal of Financial Economics, Vol. 49, No. 3, pp. 283-306.

Fama, E. F. and French, K. R. (1988) 'Permanent and temporary components of stock prices'. The Journal of Political Economy, Vol. 96, No. 2., pp. 246-273.

Fama, E.F. and Schwert, G.W. (1977) 'Asset returns and inflation'. Journal of Financial Economics, Vol. 5, pp. 115-146.

Farnham, P.G. (2009). Economics for Managers, $2^{\text {nd }}$ edition, Harlow, Prentice Hall, Pearson Education.

Fase, M.M.G. and Abma, R.C.N. (2003) 'Financial environment and economic growth in selected Asian countries'. Journal of Asian Economics, Vol. 14: pp. 11-21.

Ferson, W.E. and Harvey, C.R. (1998) 'Fundamental determinants of national equity markets returns: A perspective on conditional asset pricing'. Journal of Banking and Finance, Vol. 21, pp. 1625-1665.

Filis, G., Degiannakis, S. and Floros, C. (2011) 'Dynamic correlation between stockmarket and oil prices: the case of oil-importing and oil-exporting countries'. International Review of Financial Analysis, Vol. 20, pp. 152164.

Fisher, I. (1930) The Theory of Interest. McMillan: New York.

Flannery, M.J. and James, C. (1984) 'The effect of interest rate changes on the common stock returns of financial institution', The Journal of Finance, Vol. 39, No. 4, pp. 1141-1153.

Franck, P. and Young, A. (1972) 'Stock price reaction of multinational firms to exchange realignments'. Financial Management, Vol., pp. 66-73.

Frenkel, J. (1976) 'A monetary approach to the exchange rate: doctrinal aspects and empirical evidence'. Scandinavian Journal of Economics, Vol. 78, pp. 200-224.

Gabem J.B., Tuomas, A.P. and Daniel, S. (2010) ‘Booms and busts in China’s stock market: Estimates based on fundamentals', European Central Bank, Working paper series, No. 1190.

Gallagher, L. and Taylor, M.P. (2002) 'The stock return-inflation puzzle revisited'. Economics Letters, Vol. 75, pp. 147-56.

Garefalakis, A.E., Dimitras, A., Koemtzopoulos, D. and Spinthiropoulos, K. (2010) 'Determinant factors of Hong Kong Stock Market', abstract from URL: ssrn.com/abstract $=1762162$

Gilbert, C.L. (2008) ‘Commodity speculation and commodity investments'. Working paper. 
Bin, W., \& Celis, E. E. (2017). Causal Relationship of Stock Performance and Macroeconomic Variables: Empirical Evidences from Brazil, Russia, India and China (BRIC). Archives of Business Research, 5(3), 11-39

Giovannini, A. and Jorion, P. (1987) 'Interest rates and risk premia in the stock market and in the foreign exchange market'. Journal of International Money and Finance, Vol. 6, pp. 107-124.

Gordon, M.J. (1959) 'Dividends, earnings and stock prices'. Review of Economics and Statistics, Vol. 41, No. 2, pp. 99-105.

Gordon, M.J. and Shapiro, E. (1956) 'Capital equipment analysis: The required rate of profit', Management Science, Vol. 3, No. 1, pp. 102-110.

Granger, C.W.J. and Newbold, P. (1974) 'Spurious regression in econometrics'. Journal of Econometrics, Vol. 2, pp. 111-120.

Green, T. C. (2004) 'Economic news and the impact of trading on bond prices', The Journal of Finance, Vol. 59, No. 3, pp. 1201-1233.

Greenwood, J. and Smith, B. (1997) 'Financial markets in development, and the development of financial markets'. Journal of Economic Dynamics and Control, Vol. 21. pp. 141-181.

Groenewold, N. and Ariff, M. ( 1999) 'The effects of deregulation on share market efficiency in the Asia-Pacific', International Economic Journal, Vol. 12, No. 4, pp. 23-47.

Gultekin, N.B. (1983) 'Stock market returns and inflation: Evidence from other countries'. Journal of Finance, Vol. 38, pp. 49-65.

Hammoudeh, S. and Choi, K. (2006) 'Behavior of GCC stock markets and impacts of US oil and financial markets'. Research in International Business and Finance, Vol. 20, pp. 22-44.

Hawawini, G. and Keim, D. B. (1995) 'On the predictability of common stock return - world-wide evidence', Handbooks in Operations Research and Management Science, Vol. 9, 1995, pp. 497-544.

Holmes, D. (2006) 'A financial feast: A-la-carte commodity investing”, The London Bullion Market Association, Alchemy, Vol. 43, pp. 10-12.

Holmstrom, B. and Tirole, J. (1993) 'Market liquidity and performance monitoring', Journal of Political Economy, Vol. 101, No. 4, pp. 678-709.

Humpe, A. and Macmillan, P. (2009) 'Can macroeconomic variables explain long-term stock market movements? A comparison of the US and Japan'. Applied Financial Economics, Vol. 19, No. 2, pp. 111-119

Hunter, J.E. and Coggin, T.A. (1988) 'Analyst judgment - The efficient market hypothesis versus a psychological theory of human judgment', Organizational Behavior and Human Decision Processes, Vol. 42, No. 3, pp. $284-302$.

Jaffe, J.F. and Mandelker, G. (1976) 'The 'Fisher Effect' for risky assets: An empirical investigation'. Journal of Finance, Vol. 31, pp. 447-458.

Jammazi, R. (2012) 'Oil shock transmission to stock market returns: Wavelet multivariate markov switching GARCH approach'. Energy, Vol. 37, No. 430-454.

Jensen, M. C. (1978) 'Some anomalous evidence regarding market efficiency', Journal of Financial Economics, Vol. 6, No. 2-3, pp. 95-101.

Jesus, G.G. and Yue, Y. (2010) 'International determinants of stock market performance in China: A cointegration approach', University of the West of England, Working paper series, No. 03/10.

Johansen, S. (1991) 'Estimation and hypothesis testing of cointegration vectors in Gaussian vector autoregressive models'. Econometrica, Vol. 59, pp. 1551-1580.

Jones, C.M. and Kaul, G. (1996) 'Oil and the stock markets'. The Journal of Finance, Vol. 51, pp. 463-491.

Keim, D.B. and Stambaugh, R.F. (1986) 'Predicting returns in the stock and bond markets', Journal of Financial Economics,Vol. 17, No. 2, pp. 357-390.

Keynes, J.M. (1936) The General Theory of Employment, Interest and Money, Published by Palgrave Macmillan.

Kim, K. (2003). 'Dollar exchange rate and stock price: evidence from multivariate cointegration and error correction model'. Review of Financial Economics, Vol. 12, pp. 301-313.

Kiyotaki, N. and Moore, J. (1997) 'Credit cycles', Journal of Political Economy, Vol. 105, pp. 211-248. 
Korajczyk, R. (1996) 'A measure of stock market integration for developed and emerging markets', The World Bank Economic Review, Vol. 10, No. 2, pp. 267-289.

Kwiatkowski, D., Phillips, P.C.B., Schmidt, P. and Shin, Y. (1992) 'Testing the null hypothesis of trend stationanity'. Journal of Econometrics, Vol. 54, pp. 159-178

La Porta, R., Florencio, L. and Andrei, S. (1997) 'Legal determinants of external finance,” Journal of Finance, Vol. 52, pp. 113-150.

Lee, B.S. (2010) 'Stock returns and inflation revisited: An evaluation of the inflation inllusion hypothesis', Journal of Banking and Finance, pp. 1257-1273.

Lee, Y.H. and Chiou, J.S. (2011) 'Oil sensitivity and its asymmetric impact on the stock market’. Energy, Vol. 36, pp. 168-174.

Levine, R. and Renelt, D. (1992) 'A sensitivity analysis of cross-country growth regressions', American Economic Review, Vol. 82, pp. 942-963.

Levine, R. and Zervos, S. (1998) 'Stock markets, banks, and economic growth'. American Economic Review, Vol. 88, pp. 537-558.

Liew, V.K.S. (2004) 'Which lag length selection criteria should we employ?'. Economics Bulletin, Vol. 3, No. 3, pp. 1-9.

Macdonald, R. and Taylor, M. (1992) 'Exchange rate economics: A Survey'. IMF staff papers, Vol. 39, pp. 1-57.

MacKinnon, J.G., Haug, A.A. and Michelis, L. (1999) 'Numerical distribution functions of likelihood ratio tests for cointegration'. Journal of Applied Econometric, Vol. 14, pp. 563-577.

Malkiel, B. G. (2005) 'Reflections on the efficient market hypothesis: 30 years later', Financial Review, Vol. 40, No. 1, pp. 1-9.

Malkiel, B.G. (2003) 'The efficient market hypothesis and its critics', Journal of Economic Perspectives, Vol.17, No. 1, pp. 59-82.

Masih, R., Peters, S. and De Mello, L. (2011) ‘Oil price volatility and stock price fluctuations in an emerging market: Evidence from South Korea’. Energy Economics, Vol. 33, pp. 975-986.

Miambo, C. and Biekpe, N. (2007) 'The efficient market hypothesis: Evidence from ten African stock markets'. Investment Analysts Journal, No. 66, pp. 5-18.

Miller, J.I. and Ratti, R.A. (2009) 'Crude oil and stock markets: stability, instability, and bubbles'. Energy Economics, Vol. 31, No. 4, pp. 559-568.

Modigliani, F. (1971) 'Consumer spending and monetary policy: the linkages,' Federal Reserve Bank of Boston Conference Series: Paper, No. 5.

Mohamad, R. and Mahmood, W.M.W. (2001) 'Volatility of stock index and exchange rates in Malaysia during economic crisis'. 8th Asian Pacific Finance Association Conference, Vol. 20.

Mohanty, S.K., Nandha, M., Turkistani, A.Q. and Alaitani, M.Y. (2011) 'Oil price movements and stock market returns: evidence from Gulf Cooperation Council (GCC) countries'. Global Finance Journal, Vol. 22, pp. 42-55.

Mosconi R, and Giannini, C., (1992) 'Non-causality in cointegrated systems: representation, estimation and testing'. Oxford Bulletin of Economics and Statistics, Vol. 54, pp. 399-417.

Murkherjee, T. and A. Naka (1995) 'Dynamic linkages between macroeconomic variables and the Japanese stock market. An application of a vector error correction model'. Journal of Financial Research, Vol. 18, pp. 223237.

Najang, D. and Seifert, B. (1992) 'Volatility of exchange rates, interest rates, and stock returns'. Journal of Multinational Financial Management, Vol. 2, pp. 1-19.

Narayan, P.K. and Narayan, S. (2010) ;Modelling the impact of oil prices on Vietnam's stock prices'. Applied Energy, Vol. 87, pp. 356-361.

Nelson, C.R. and Schwert, G.W. (1977) 'Short-term interest rates as predictors of inflation: On testing the hypothesis that the real rate of interest is constant'. American Economic Review, Vol. 67, pp. 478-486. 
Bin, W., \& Celis, E. E. (2017). Causal Relationship of Stock Performance and Macroeconomic Variables: Empirical Evidences from Brazil, Russia, India and China (BRIC). Archives of Business Research, 5(3), 11-39

Nieuwerburgh, S.B.F. and Ludo, C. (2006) 'Stock market development and economic growth in Belgium'. Explorations in Economic History, V. 43 No. 1, Vol. 13-38.

Obstfeld, M. (1994) 'Risk-taking, global diversification, and growth', American Economic Review, Vol. 84, No. 5, pp. 1310-1329.

Osterwald-Lenum, M. (1992) 'Practitioner's corner: a note with quantiles of the asymptotic distribution of the maximum likelihood cointegration rank test statistics'. Oxford Bulletin of Economics and Statistics, Vol. 54, pp. 461-472.

Papapetrou, E. (2001) 'Oil price shocks, stock market, economic activity and employment in Greece'. Energy Economics, Vol. 23, pp. 511-532.

Pebbles, G. and Wilson, P. (1996) The Singapore economy. Cheltenham. Edward Elgar: UK.

Perron P. (1989) 'The great crash, the oil price shock, and the unit root hypothesis'. Econometrica, Vol. 57, pp. 1361-1401.

Pesaran, M.H., Shin, Y. and Smith, R.J. (2001) 'Bounds testing approaches to the analysis of level relationships'. Journal of Applied Econometrics, Vol. 16, No. 3, pp. 289-326.

Phillips, P.C.B. and Perron, P. (1988) 'Testing for a unit root in time series regession'. Biometrika, Vol. 75, No. 2, pp. 335-346.

Quayes, S. and Jamal, A. (2008) ‘Does inflation affect stock prices?'. Applied Economics Letters, Vol. 15, No. 10, pp. 767-769,

Rahman, A.A., Noor, Z.S. and Fauziah H.T. (2009) 'Macroeconomic determinants of Malaysian stock market'. African Journal of Business Management, Vol. 3, No. 3, pp. 95-106.

Rapach, D.E. (2002) 'The long-run relationship between inflation and real stock prices'. Journal of Macroeconomics, Vol. 24, pp. 331-351.

Ray, P. and Chatterjee, S. (2001) 'The role of asset prices in Indian inflation in recent years: some conjectures', Researve Bank of India.

Ross, S.A. (1976) 'The arbitrage theory of capital asset pricing'. Journal of Economic Theory, Vol. 13, No. 3, pp. 341-360.

Sadorsky, P. (1999) 'Oil price shocks and stock market activity'. Energy Economics, Vol. 21, No. 5, pp. 449-469.

Salahuddin, M. (2010) 'The determinants of economic growth in Pakistan: Does stock market development pay a major role?', International Conference on Applied Economics, pp. 681-689

Samuelson P. (1965) 'Proof that properly anticipated prices fluctuate randomly', Industrial Management Review, Vol. 6, No. 1, pp. 41-49

Samuelson, P.A. (2010). Economics, $1^{\text {st }}$ edition. McGraw-Hill Education: Tata.

Sariannidis, N., Giannarakis, G., Litinas, N. and Konteos, G. (2010) 'GARCH examination of macroeconomic effects on U.S. stock market: A distinguish 14 between the total market index and the sustainability index'. European Research Studies, Vol. 13, pp. 129-142.

Schwert, G.W. (1989) 'Why does stock market volatility change over time?'. Journal of Finance, Vol. 44, No. 5, pp. 1115-1145.

Sharma, G.D. and Mahendru, M. (2009) 'Efficient hypothesis of the stock markets: A case of Indian securities'. International Journal of Business and Management, Vol. 4, No. 3, pp. 136-144.

Solnik, B. (1974) 'The international pricing of risk: an empirical investigation of the world capital market structure'. Journal of Finance, Vol. 29, 365-378.

Soydemir, G. (2000) 'International transmission mechanism of stock market movements: Evidence from emerging equity markets'. Journal of Forecasting, Vol. 19, pp. 146-176.

Spyrou, S.I. (2004) 'Are stocks a good hedge against inflation? Evidence from emerging markets'. Applied Economics, Vol. 36, pp. 41-48. 
Stanislav, A. (2006) 'A ten-year retrospective on the determinants of Russian stock returns', Moscow New Economic School.

Timmerman, A. and Granger, C. W. J. (2004) 'Efficient market hypothesis and forecasting'. International Journal of Forecasting, Vol. 20, No. 1, pp. 15-27.

Tobin, J. (1969) 'A general equilibrium approach to monetary theory'. Journal of Money, Credit, and Banking, Vol. 1, pp. 15-29.

Tully, E., and Lucey, B.M. (2005) 'An APGARCH investigation of the main influences on the gold price'. University of Dublin Trinity College, Working Paper, August 2005.

Umstead, D.A. (1977) 'Forecasting stock market price'. The Journal of Finance, Vol. 32, No. 2, pp. 427-441.

Uri, N.D. and Jones, J.D. (1990) 'Are the markets for financial assets efficient?: Evidence for the USA, 19741988'. Economic Modeling, Vol. 7, No. 4, pp. 388-394.

Wu, J., Hou, H. and Cheng, S. (2009) 'The dynamic impacts of financial institutions on economic growth: Evidence from the European Union', Journal of Macroeconomics.

Yohannes, L.G (1994) 'Macroeconomic policy and stock market efficiency in Nigeria: A case study'. African Economic Research Consortium Publication.

Zhang, C. and Chen, X. (2011) 'The impact of global oil price shocks on China's stock returns: evidence from the ARJI(-ht)-EGARCH model'. Energy, Vol. 36, No. 66, pp 